\title{
Unusual metastatic sex cord stromal tumor - staging and response assessment
}

\author{
Namita Agrawal ${ }^{1 *}$, Tarun Kumar Jain ${ }^{2}$, Guman Singh ${ }^{3}$, Hemant Malhotra ${ }^{4}$, Ajay Yadav ${ }^{4}$
}

\begin{abstract}
${ }^{1}$ Department of Obstetrics and Gynecology, Santokba Durlabhji Memorial Hospital, Jaipur, Rajasthan, India ${ }^{2}$ Department of Nuclear Medicine, Mahatma Gandhi Medical College and Hospital Jaipur, Rajasthan, India ${ }^{3}$ Department of Radiation Oncology, Mahatma Gandhi Medical College and Hospital Jaipur, Rajasthan, India ${ }^{4}$ Department of Medical Oncology, Mahatma Gandhi Medical College and Hospital Jaipur, Rajasthan, India
\end{abstract}

Received: 28 April 2020

Accepted: 30 May 2020

\section{*Correspondence:}

Dr. Namita Agrawal,

E-mail: namitaagarwalsms@gmail.com

Copyright: () the author(s), publisher and licensee Medip Academy. This is an open-access article distributed under the terms of the Creative Commons Attribution Non-Commercial License, which permits unrestricted non-commercial use, distribution, and reproduction in any medium, provided the original work is properly cited.

\begin{abstract}
Metastatic sex cord stromal tumor (SCST) is rare and contributing <1\% of ovarian tumors. A 42 -year-old female presented with lower abdominal pain for 2 months. Ultrasonography revealed masses in the abdominal and pelvic. USG guided biopsy from the pelvic mass revealed SCST. For staging, whole body F-18 fluorodeoxyglucose positron emission tomography-computed tomography was performed and revealed heterogenous mildly FDG avid retroperitoneal and bilateral pelvic masses with lung nodules. To confirm the nature of the lung nodule; PET-CT guided biopsy performed and revealed metastatic SCST. After three cycle of chemotherapy, clinical, biochemical and imaging show partial response to treatment.
\end{abstract}

Keywords: F-18 fluorodeoxyglucose positron emission tomography-computed tomography, Metastatic sex cord stromal tumor, Metabolic biopsy

\section{INTRODUCTION}

Sex cord-stromal tumors of ovary are uncommon tumors. Histopathologically, they are differing from epithelial tumors of the ovary and arises from the primitive sex cords or stromal cells. These cell types may be present separately or admixed and display 3 main categories of tumors: pure stromal tumors, pure sex cord tumors, and mixed sex cord-stromal tumors. ${ }^{2,3}$ Age wise distribution of the tumor is wide. The clinical presentation may be due to either mass effect of the lesion or sex steroid hormonal production by the tumors. ${ }^{4,5}$ Most of the tumors are low-grade disease (stage I) and usually follows a nonaggressive clinical course. Therefore, the primary treatment is surgical and the prognosis is favorable. ${ }^{1}$ The distant metastasis in this subgroup of ovarian tumor is rare and responsible for poor outcome. ${ }^{6,7}$ Ultrasound is common initial imaging modality. Cross-sectional imaging's, like CT or MRI, show an adnexal mass or masses. Whole body F-18 FDG PET/CT is an integral step for evaluation of patients with diagnosed and suspected malignancy. ${ }^{8}$ Many of the sex cord-stromal tumors is misleading like higher stage at initial stage and often follows a more aggressive course and associated with a fatal outcome. ${ }^{9}$ In present case authors highlighted the utility of F-18 FDG PET-CT in metastatic sex cord stromal tumor.

\section{CASE REPORT}

A 42-year-old female presented with lower abdominal pain for 2 months. Pain was dull in nature and remains throughout the day in variable intensity. She was on regular analgesics but no significant improvement was noted. She has a past history of hysterectomy 18 year back due to non-specific complains. There was no other significant contributory past and family history. 

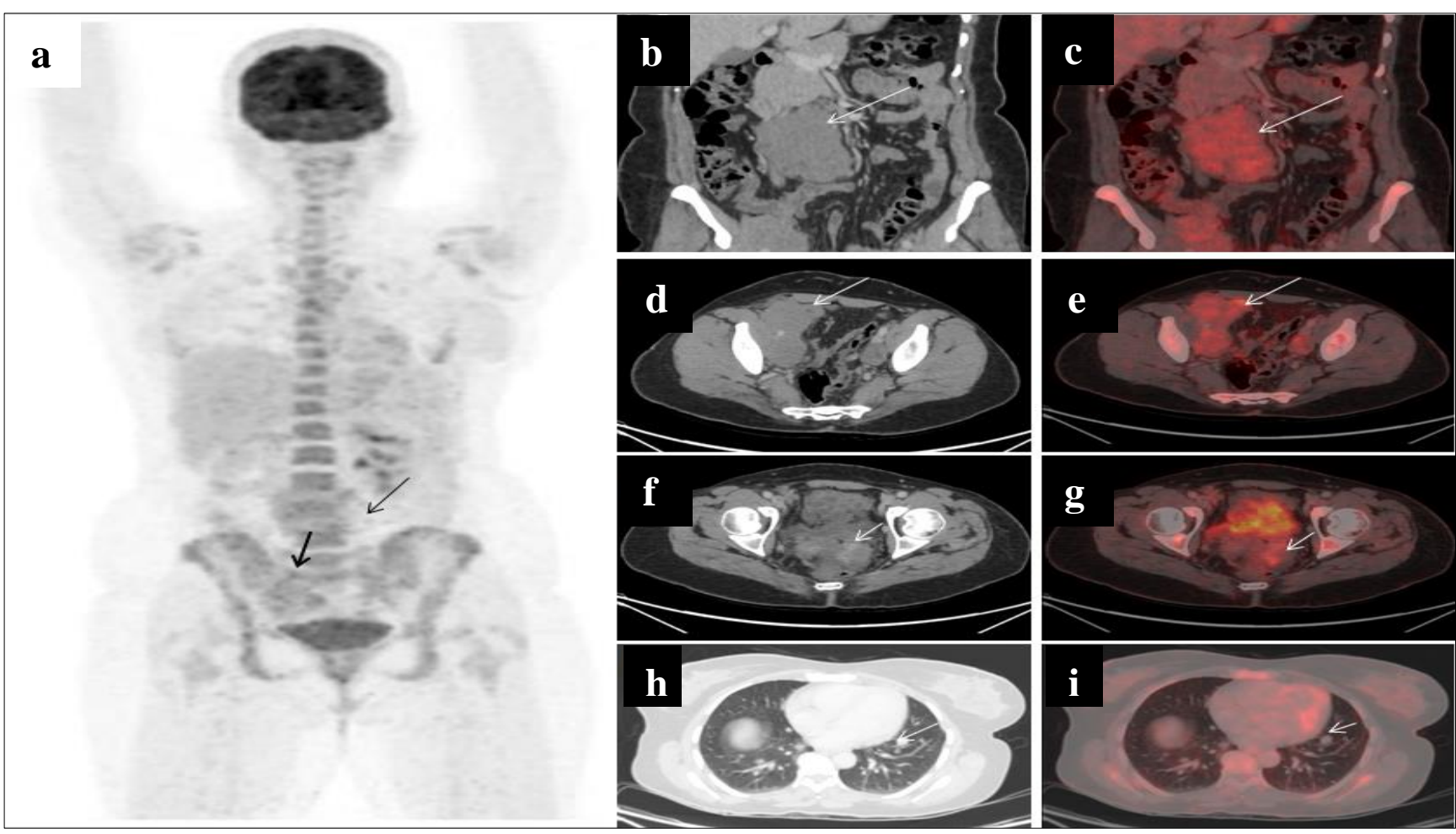

Figure 1: F-18 FDG PET MIP (Figure 1a) reveals abnormal ill-defined hot spots in the midline lower abdomen and pelvic regions (arrows). Corresponding coronal and trans-axial CECT and fused PET-CT (Figure 1b-i) reveal heterogeneous mildly FDG avid heterogeneously enhancing soft tissue masses in pre and paraaortic region at the level of the L3-L5 vertebrae (SUVmax 4.5; $\sim 6.6 \times 8.3 \times 8.3 \mathrm{~cm}$ ) (Figure 1b-c), bilateral external (right side SUVmax $3.0 ; \sim 4.2 \times 3.7 \mathrm{~cm}$ ) (left side SUVmax 3.8; 3.3×3.0 cm) (Figure d-e) and right internal iliac (SUVmax 3.8; 4.9×4.8

$\mathrm{cm}$ ) region and left side of the vaginal vault (SUVmax 4.1; 3.8 $\times 3.8 \mathrm{~cm}$ ) (Figure $1 \mathrm{f}-\mathrm{g}$ ). Low grade FDG avid (SUVmax 1.8) variable sized a few pleural based and parenchymal lung nodules (Figure $1 \mathrm{~h}$-i) are also noted in the bilateral lung fields.

On general and physical examination, there were palpable abdominal and pelvic masses. USG abdomen reveals $\sim 80 \times 37 \times 45 \mathrm{~mm}$ sized mass lesion in the right adnexa and $\sim 79 \times 47 \times 72 \mathrm{~mm}$ sized soft tissue mass in the paraaortic region at umbilical level. USG guided biopsy from the right pelvic mass reveal sex cord stromal tumor. After the IHC analysis, tumor cells were immune-positive for calretinin (dim), Inhibin (dim) and ER and immunenegative for CK, EMA, SALL4 and chromogranin. On biochemical analysis, CA-125 23.1 U/ml $(<35.0)$, alpha feta protein (AFP) $\sim 6.84 \mathrm{IU} / \mathrm{ml}(<7.22 \mathrm{IU} / \mathrm{ml})$, inhibin A $\sim 92.2 \mathrm{pg} / \mathrm{ml}(<1.0-2.0)$, inhibin $\mathrm{B} \sim 82.4 \mathrm{pg} / \mathrm{ml}(<33.0), \beta$ human chorionic gonadotrophin hormone $<2.39 \mathrm{mIU} / \mathrm{ml}$ (0-5), lactate dehydrogenase (LDH) 271.3 U/1 (313-618) were noted. For disease staging whole body F-18 fluorodeoxyglucose positron emission tomographycomputed tomography (F-18 FDG PET-CT) was performed. PET-CT revealed low grade FDG avid variable sized a few pleural based and parenchymal lung nodules, heterogeneous mildly FDG avid heterogeneously enhancing soft tissue masses in the retroperitoneum (SUVmax $4.5 ; \sim 6.6 \times 8.3 \times 8.3 \mathrm{~cm}$ ) at the level of the L3 -L5 vertebrae, bilateral external regions (right side SUVmax $3.0 ; \sim 4.2 \times 3.7 \mathrm{~cm}$ ) (left side SUVmax $3.8 ; \sim 3.3 \times 3.0 \mathrm{~cm}$ ) and right internal iliac region (SUVmax $3.8 ; \sim 4.9 \times 4.8 \mathrm{~cm}$ ) and left side of the vaginal vault (SUVmax $4.1 ; \sim 3.8 \times 3.8 \mathrm{~cm}$ ) as shown in Figure 1. PET-CT guided biopsy was performed from the lung nodule and revealed metastatic sex cord stromal tumor. Patient was scheduled for chemotherapy (bleomycin, etoposide and cisplatinin). After the 3 cycle of chemotherapy there was significant improvement on abdominal pain was noted. On biochemical analysis; Inhibin A $\sim 12.2 \mathrm{pg} / \mathrm{ml}(<1.0-2.0)$ and Inhibin B $\sim 34.4$ $\mathrm{pg} / \mathrm{ml}(<33.0)$ were noted. Follow-up PET-CT showed significant decreased in size, number and SUVmax of the lung nodules, retroperitoneal and pelvic masses.

\section{DISCUSSION}

Sex cord-stromal tumors of ovary comprise $\sim 5-7 \%$ of all primary ovarian tumors. ${ }^{1}$ Histopathologically, this group of tumor is arising from stromal cells like theca cells, fibroblasts, and Leydig cells whereas the primitive sex cords include granulosa cells and Sertoli cells. These tumors are classified into 3 main categories: pure stromal 
tumors, pure sex cord tumors, and mixed sex cordstromal tumors. So, when ovarian sex cord-stromal tumor is suspected, levels of inhibin, estradiol, testosterone, and AFP should be obtained. Inhibin levels may be elevated in granulosa cell tumors. ${ }^{11}$ Granulosa cell tumors may also present with elevated estradiol, and Sertoli-Leydig cell tumors may present with elevated testosterone or, rarely AFP. ${ }^{10}$

Most of the tumors are have a favorable nonaggressive clinical course. The lymph node and lung metastasis in this subgroup of ovarian tumor is very rare $(\sim 1 \%)$ and responsible for poor outcome. ${ }^{6,7}$ As like other ovarian tumors, disease distribution may be difficult to determine with limited field imaging so whole body PET-CT should be performed because many of the sex cord-stromal tumors is misleading like higher stage or residual recurrent disease often follows a more aggressive course and associated with a fatal outcome. ${ }^{10,11}$ In present case authors highlight the imaging and biochemical benefits in the metastatic granulosa cell tumors.

\section{Funding: No funding sources}

Conflict of interest: None declared

Ethical approval: Not required

\section{REFERENCES}

1. Horta M, Cunha TM. Sex cord-stromal tumors of the ovary: a comprehensive review and update for radiologists. Diagn Interv Radiol. 2015;21(4):27786.

2. Haroon S, Zia A, Idrees R, Memon A, Fatima S, Kayani N. Clinicopathological spectrum of ovarian sex cord-stromal tumors; 20 years' retrospective study in a developing country. J Ovarian Res. 2013;6:87.

3. Shim SH, Kim DY, Lee SW, Park JY, Kim JH, Kim YM, et al. Laparoscopic management of early-stage malignant non-epithelial ovarian tumors: surgical and survival outcomes. Int $\mathbf{J}$ Gynecol Cancer. 2013;23:249-55.

4. Hanley KZ, Mosunjac MB. Practical review of ovarian sex cord-stromal tumors. Surg Pathol Clin. 2019;12:587-620.
5. Gupta N, Yadav M, Gupta V, Chaudhary D, Patne SCU. Distribution of various histopathological types of ovarian tumors: a study of 212 cases from a tertiary care center of Eastern Uttar Pradesh. J Lab Physicians. 2019;11(1):75-81.

6. Thrall MM, Paley P, Pizer E, Garcia R, Goff BA. Patterns of spread and recurrence of sex cord-stromal tumors of the ovary. Gynecol Oncol. 2011;122(2):242-5.

7. Brown J, Sood AK, Deavers MT, Milojevic L, Gershenson DM. Patterns of metastasis in sex cordstromal tumors of the ovary: can routine staging lymphadenectomy be omitted? Gynecol Oncol. 2009;113(1):86-90.

8. Sharma P, Jain TK, Parida GK, Karunanithi S, Patel C, Sharma A, et al. Diagnostic accuracy of integrated (18)F-FDG PET/CT for restaging patients with malignant germ cell tumours. $\mathrm{Br} \mathrm{J}$ Radiol. 2014;87(1040):263.

9. Nasioudis D, Orfanelli T, Frey MK, Chapman-Davis E, Caputo TA, Witkin SS, et al. Role of adjuvant chemotherapy in the management of non-granulosa cell ovarian sex cord-stromal tumors. J Gynecol Oncol. 2019; 30(2):e19.

10. Schultz KA, Harris AK, Schneider DT, Young RH, Brown J, Gershenson DM, Dehner LP, Hill DA, Messinger YH, Frazier AL. Ovarian sex cord-stromal tumors. J Oncol Pract. 2016;12(10):940-6.

11. Schneider DT, Orbach D, Cecchetto G, StachowiczStencel T, Brummel B, Brecht IB, et al. Ovarian sertoli leydig cell tumours in children and adolescents: an analysis of the european cooperative study group on pediatric rare tumors (EXPeRT). Eur J Cancer. 2015;51:543-50.

Cite this article as: Agrawal N, Jain TK, Singh G, Malhotra H, Yadav A. Unusual metastatic sex cord stromal tumor - staging and response assessment. Int J Reprod Contracept Obstet Gynecol 2020;9:3072-4. 